\title{
AGPAT6 polymorphism and its association with milk traits of dairy goats
}

\author{
C. He ${ }^{1}$, C. Wang ${ }^{1}$, Z.H. Chang ${ }^{1}$, B.L. Guo ${ }^{1}$, R. Li ${ }^{1}$, X.P. Yue ${ }^{1}$, X.Y. Lan ${ }^{1}$, \\ H. Chen ${ }^{1,2}$ and C.Z. Lei ${ }^{1}$
}

${ }^{1}$ Shaanxi Key Laboratory of Molecular Biology for Agriculture, College of Animal Science and Technology, Northwest A \& F University, Yangling, Shaanxi, China

${ }^{2}$ Institute of Cellular and Molecular Biology, Xuzhou Normal University, Xuzhou, Jiangsu, China

Corresponding author: C.Z. Lei

E-mail: leichuzhao1118@126.com

Genet. Mol. Res. 10 (4): 2747-2756 (2011)

Received January 4, 2011

Accepted August 15, 2011

Published November 4, 2011

DOI http://dx.doi.org/10.4238/2011.November.4.8

\begin{abstract}
As one of the eight members in the 1-acylglycerol-3phosphate-O-acyltransferase (AGPATs) family, AGPAT6 is a crucial enzyme for the biosynthesis of glycerolipids and triacylglycerol in eukaryotes, as well as catalyzing the conversion from lysophosphatidic acid to phosphatidic acid. AGPAT6 can be considered as a candidate gene for regulating milk composition. DNA sequencing and PCRRFLP methods were applied to detect genetic variation in the AGPAT6 gene in 549 Chinese dairy goats. Four polymorphisms (NC_007328.3:g.152G $>$ C , 8124G $>$ A, 9263C $>$ G, 16436G $>$ A) were detected in 5'UTR, intron 2, exon 4, and 3'UTR, respectively. For the $K p n I$ locus, the frequencies of the AGPAT6-G allele were 0.955 and 0.936 for SN (Xinong Sannen) and GZ (Guanzhong) dairy goat breeds, respectively. In the PCR-RFLP analysis for KpnI, EcoRII, NcoI, and $B g l \mathrm{I}$, the frequencies of the $\mathrm{G}$ allele of AGPAT6 were 0.955 and 0.936 , 0.694 and $0.819,0.206$ and $0.254,0.729$ and 0.623 for SN and GZ dairy goat breeds, respectively. The $9263 \mathrm{C}>\mathrm{G}$ mutation revealed a synonymous genetic code of Thr (threonine). Associations between the
\end{abstract}


four mutations and milk traits were analyzed in two dairy goat breeds. At the $9263 \mathrm{C}>\mathrm{G}$ locus, genotype $\mathrm{GG}$ and $\mathrm{CG}$ individuals showed significantly better milk performance than genotype $\mathrm{CC}$ individuals $(\mathrm{P}$ $<0.05$ ). Therefore, the $\mathrm{G}$ allele is suggested to be a molecular marker for milk production in dairy goats.

Key words: Dairy goat; AGPAT6 gene; Polymorphism; PCR-RFLP; Milk traits

\section{INTRODUCTION}

The 1-acylglycerol-3-phosphate-O-acyltransferase (AGPAT) enzyme is crucial for the synthesis of glycerolipids as well as triacylglycerol biosynthesis in eukaryotes (Ye et al., 2005). It catalyzes the conversion of lysophosphatidic acid (LPA) to phosphatidic acid (PA) (Aguado and Campbell, 1998; Coleman and Lee, 2004; Agarwal et al., 2006, 2007; Sukumaran et al., 2009). So far, eight members of the AGPAT family in human have been described, which are AGPAT1 , 2, 3, 4, 5, 6, 7, and 8 (Ye et al., 2005), and all of them possess LPAAT (lysophosphatidic acid acyltransferase) motifs (Nagle et al., 2008). AGPAT6 is one of the eight AGPAT isoforms identified through sequence homology (Nagle et al., 2008). It is a novel gene similar in sequence to glycerolipid acyltransferases (Agarwal et al., 2007). Although AGPAT family members share certain amino acid sequence similarities, AGPAT6's closest family member is another novel gene, AGPAT8, and both of them are conserved from plants, nematodes, and flies to mammals (Beigneux et al., 2006). AGPAT6 is highly expressed in mammary epithelium of breast tissue (Beigneux et al., 2006). It has been implicated in triglyceride synthesis in mammary glands and has been recognized as microsomal glycerol-3-phosphate acyltransferase (GPAT), which catalyzes the glycerolipid biosynthesis pathway (Beigneux et al., 2006).

Based on the regulatory roles of the AGPAT6 gene in glycerolipid biosynthesis catalysis and milk fat production, the AGPAT6 gene could be considered as a potential gene for milk composition. Therefore, the objectives of this study are to detect SNPs of the AGPAT6 gene in dairy goats and explore their possible association with milk traits in two Chinese dairy goat breeds.

\section{MATERIAL AND METHODS}

\section{DNA samples}

Five hundred and forty-nine blood samples were obtained from two Chinese dairy goat breeds including Xinong Sannen ( $\mathrm{SN}, \mathrm{N}=268)$ and Guanzhong $(\mathrm{GZ}, \mathrm{N}=281)$. Genomic DNA was extracted from blood samples following standard procedures (Sambrook and Russell, 2001) and stored at $-80^{\circ} \mathrm{C}$. The records of milk components including milk fat (\%), protein $(\%)$ and milk yield $(\mathrm{kg})$ from all animals (1 year old) were collected for statistical analysis.

\section{Primer design and polymerase chain reaction (PCR) amplification}

Based on GenBank sequence No. NC_007328.3, 10 pairs of PCR primers (Table 1) 
were designed to amplify $5^{\prime} \mathrm{UTR}$, exon 1-11, intron 2, partial exon 12, and 3'UTR of the goat AGPAT6 gene. The $25 \mu \mathrm{L}$ volume contained: $20 \mathrm{ng}$ genomic DNA, $0.5 \mu \mathrm{M}$ of each primer, $1 \mathrm{X}$ buffer (including $1.5 \mathrm{mM} \mathrm{MgCl}_{2}$ ), $200 \mu \mathrm{M}$ dNTPs, and $0.625 \mathrm{U}$ Taq DNA polymerase (MBI). The cycling protocol was $5 \mathrm{~min}$ at $95^{\circ} \mathrm{C}, 34$ cycles of $94^{\circ} \mathrm{C}$ for $30 \mathrm{~s}$, annealing $\left({ }^{\circ} \mathrm{C}\right)$ for $30 \mathrm{~s}$ as indicated in Table 1 and $72^{\circ} \mathrm{C}$ for $35 \mathrm{~s}$, with a final extension at $72^{\circ} \mathrm{C}$ for $10 \mathrm{~min}$.

\begin{tabular}{|c|c|c|c|c|}
\hline Loci & Primers (5'-3') & Length (bp) & $\operatorname{Tm}\left({ }^{\circ} \mathrm{C}\right)$ & Note \\
\hline P1 & $\begin{array}{l}\text { F: GAGCGGAACAGAGCCCAGAG } \\
\text { R: GGCGGGGACGATGATGAA }\end{array}$ & 386 & 58 & 7-392 (Exon 1, partial 5'UTR) \\
\hline P1-KpnI & $\begin{array}{l}\text { F: GCGGAACAGAGCCCAGAGCG } \\
\text { R: GTTCGCATCCCTCGATGGCCGGTAC }\end{array}$ & 175 & 63 & 2-176 (5'UTR) \\
\hline P2 & $\begin{array}{l}\text { F: ACCCTATGTGTTGCTGTTCC } \\
\text { R: GATGGTCTCCATTCCTTTCC }\end{array}$ & 372 & 60 & 7873-8244 (Exon 2, Intron 2) \\
\hline P3 & $\begin{array}{l}\text { F: TCTCCCAGCAGACCACCT } \\
\text { R: CGAACCCGCATGAGTAGG }\end{array}$ & 315 & 60 & 8193-8507 (Exon 3) \\
\hline P4 & $\begin{array}{l}\text { F: ATCTGGCATTTTCACACATT } \\
\text { R: CTGACTCCATCTAAGAGCCT }\end{array}$ & 241 & 53 & 9135-9375 (Exon 4) \\
\hline P5 & $\begin{array}{l}\text { F: GCTTACCGTAGACACTAATAAT } \\
\text { R: CCACTCGGCTCACAGCACCCAG }\end{array}$ & 635 & 55 & 9889-10523 (Exon 5-6) \\
\hline P6 & $\begin{array}{l}\text { F: TCTTTGTAGGGTTTTCAGTT } \\
\text { R: CTCTATATTCCACATTTCGG }\end{array}$ & 419 & 49 & 10811-11229 (Exon 7) \\
\hline P7 & $\begin{array}{l}\text { F: TTCATACCGCACCCAGCATC } \\
\text { R: AGTTCCAGGACCAGCCCAAA }\end{array}$ & 271 & 61 & 11740-12010 (Exon 8) \\
\hline P8 & $\begin{array}{l}\text { F: GCTGTCAGAGGGCTTTTACTATTC } \\
\text { R: CCGAGCTGCTGGGTTTATG }\end{array}$ & 324 & 55 & 12193-12516 (Exon 9) \\
\hline P9 & $\begin{array}{l}\text { F: CACCCCGCCCTGTCGCCC } \\
\text { R: AACCGCCTCAGAAATCCC }\end{array}$ & 371 & 61 & 15509-15879 (Exon 10-11) \\
\hline P10 & $\begin{array}{l}\text { F: TACAGGAACGAACCCCAAAC } \\
\text { R: TGGGGCACCGTCTGTCTGAG }\end{array}$ & 336 & 59 & 16298-16633 (Exon 12, 3'UTR) \\
\hline
\end{tabular}

The underlined base shows mismatches changed for creating restriction sites. Tm $=$ annealing temperature.

After amplifying the goat genomic DNA pool $(1 \mu \mathrm{L}$ from every individual) (Sham et al., 2002), PCR products were sequenced directly by ABI PRIZM 377 DNA sequencer (Perkin-Elmer) and then analyzed with the BioXM software (version 2.6).

\section{PCR restriction fragment length polymorphism (PCR-RFLP)}

The PCR-RFLP technique was used to detect the polymorphism of AGPAT6. Aliquots of $10 \mu \mathrm{L}$ PCR products of the AGPAT6 gene were digested with $10 \mathrm{U}$ restriction endonuclease (MBI fermentas) for $9 \mathrm{~h}$ at $37^{\circ} \mathrm{C}$ following supplier instructions. The digested products were detected by electrophoresis on $2.5 \%$ agarose gel stained with ethidium bromide.

\section{Statistical analysis}

Statistical analysis was performed on the basis of records of milk traits in SN and GZ breeds. Genotypic and allelic frequencies of polymorphism sites on the AGPAT6 gene were analyzed by the chi-square test for the two Chinese dairy goat breeds using the SPSS software (version 16.0). Gene homozygosity $\left(H_{\mathrm{O}}\right)$, heterozygosity $\left(H_{\mathrm{E}}\right)$, effective allele numbers $\left(N_{\mathrm{E}}\right)$, and polymorphism information content (PIC) were evaluated by Nei's methods (Nei and Roychoudhury, 1974). The association between genotypes and milk performance was analyzed 
through the general linear model (GLM) procedure of SPSS according to the following model:

$$
Y_{i j k l}=\mu+B_{i}+A_{j}+G_{k}+(B G)_{i k}+E_{i j k l}
$$

where $Y_{i j k l}$ is the trait measured on each of the $\mathrm{ijk} \mathrm{k}^{\text {th }}$ animal; $\mu$ is the overall mean; $B_{i}$ is the type of the $\mathrm{i}^{\text {th }}$ breed; $A_{j}$ is the type of the $\mathrm{j}^{\text {th }}$ age; $G_{k}$ is the type of the $\mathrm{k}^{\text {th }}$ genotype; $(B G)_{i k}$ is the interaction between the $\mathrm{i}^{\text {th }}$ breed and the $\mathrm{k}^{\text {th }}$ genotype, and $E_{i j k l}$ is the random error (Lan et al., 2007).

\section{RESULTS}

Variations of the goat AGPAT6 gene were detected by DNA sequencing and PCRRFLP methods. Four mutations (NC_007328.3:g.152G $>$ C, 8124G $>$ A, 9263C $>$ G, 16436G $>$ A) were detected in 5'UTR (P1-KpnI), intron 2 (P2), exon 4 (P4), and 3'UTR (P10), respectively. No polymorphism was detected in the remaining loci (P1, P3, P5-P9) of the goat AGPAT6 gene.

The g.9263C $>$ G mutation resulted in a synonymous genetic code of threonine, in detail, ACC (Thr) > ACG (Thr) at position 195 aa of AGPAT6 (457 aa).

A new pair of primers for the P1-KpnI (Table 1) was designed to introduce a $K p n I$ endonuclease restriction site (GGTACC) for the detection of the $152 \mathrm{G}>\mathrm{C}$ mutation, hence 175bp PCR products digested with KpnI showed two bands ( 150 and $25 \mathrm{bp}$ ) for the $\mathrm{C}$ allele and one band (175 bp) for the G allele, and indicated GG, GC and CC genotypes (Figure 1A,B).
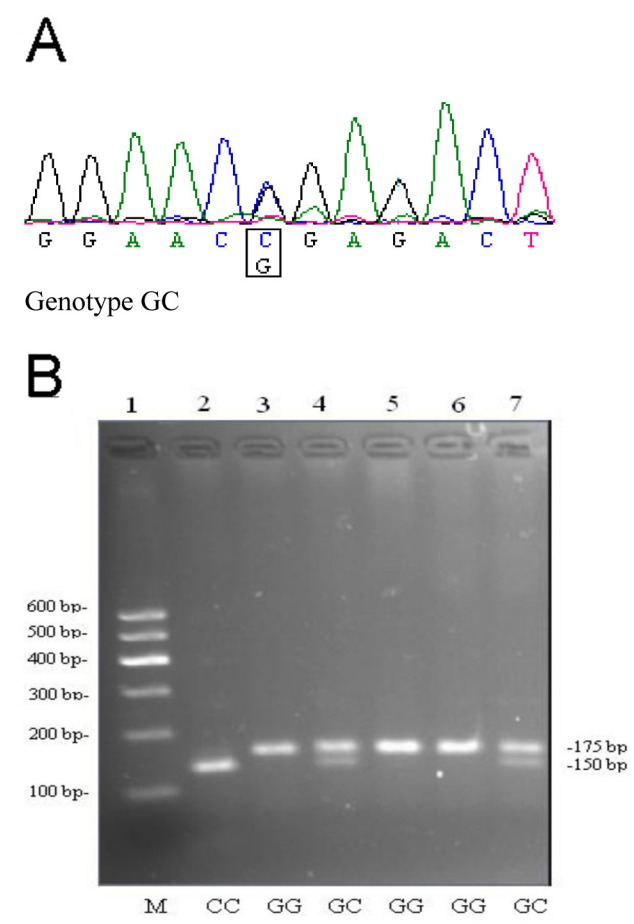

Figure 1. A. Sequencing maps at position of $\mathrm{NC} 007328.3: \mathrm{g} .152 \mathrm{G}>\mathrm{C}$ in the goat $A G P A T 6$ gene. B. Electrophoresis patterns of $K p n I$ forced PCR-RFLP analysis of the goat $A G P A T 6$ gene. GG $=175 \mathrm{bp}$; GC $=175+150+25 \mathrm{bp}$; CC $=150+25 \mathrm{bp}$. Lane $M=$ marker I $(600,500,400,300,200$, and $100 \mathrm{bp})$. 
The $8124 \mathrm{G}>\mathrm{A}$ mutation holded an EcoRII endonuclease restriction site (CCWGG), and the digestion of the 372-bp PCR products showed only one fragment (372 bp) for the G allele and two fragments (253 and $119 \mathrm{bp}$ ) for the A allele, and indicated GG, GA and AA genotypes (Figure 2A,B).

\section{A}

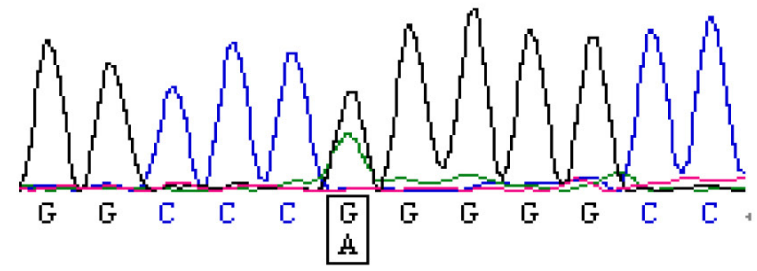

Genotype GA

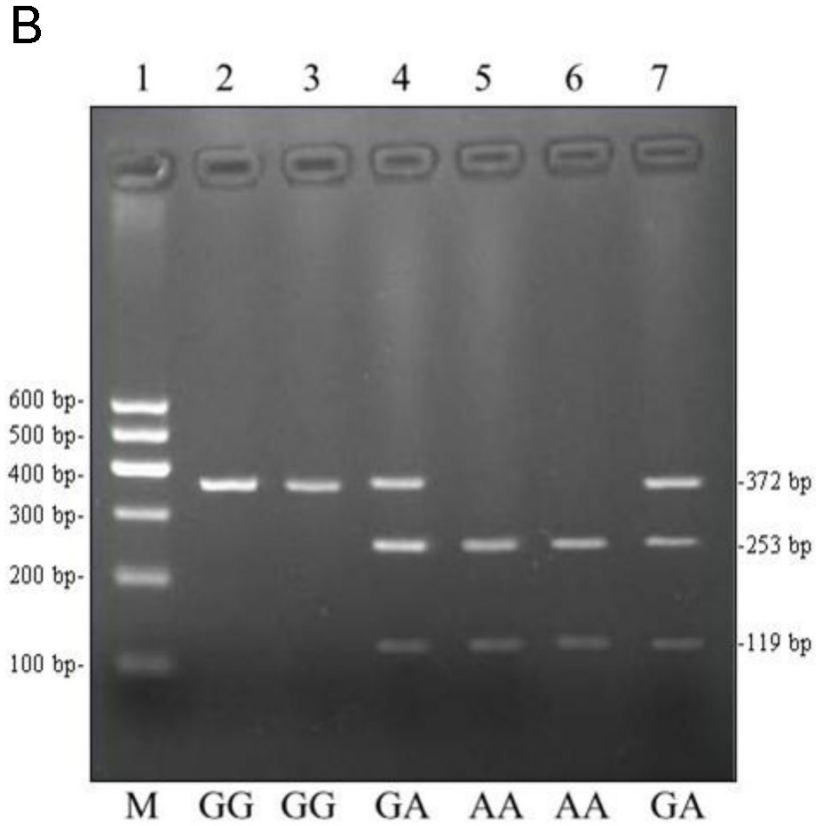

Figure 2. A. Sequencing maps at position NC_007328.3:g.8124G $>$ A in the goat AGPAT6 gene. B. Electrophoresis patterns of EcoRII PCR-RFLP analysis of the goat $A G P A T 6$ gene. $\mathrm{GG}=372 \mathrm{bp} ; \mathrm{GA}=372+253+119 \mathrm{bp}$; $\mathrm{AA}=$ $253+119$ bp). Lane $M=$ marker I (600, 500, 400, 300, 200, and $100 \mathrm{bp})$.

The 9263C $>$ G mutation added an $\mathrm{Nco}$ I endonuclease restriction site (CCATGG), and digesting by NcoI, 241-bp PCR products showed two fragments (130 and $111 \mathrm{bp}$ ) for the G allele and only one fragment ( $241 \mathrm{bp}$ ) for the $\mathrm{C}$ allele, and indicated CC, GC and GG genotypes (Figure 3A,B). 


\section{A}

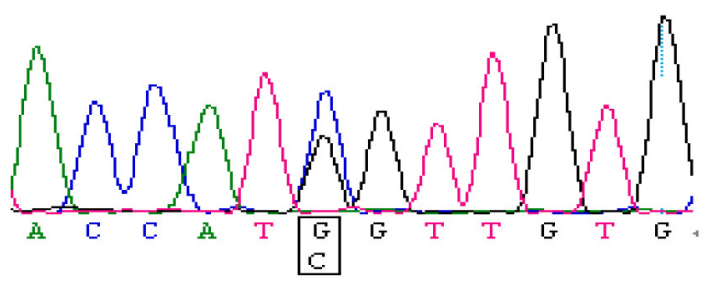

\section{Genotype CG}

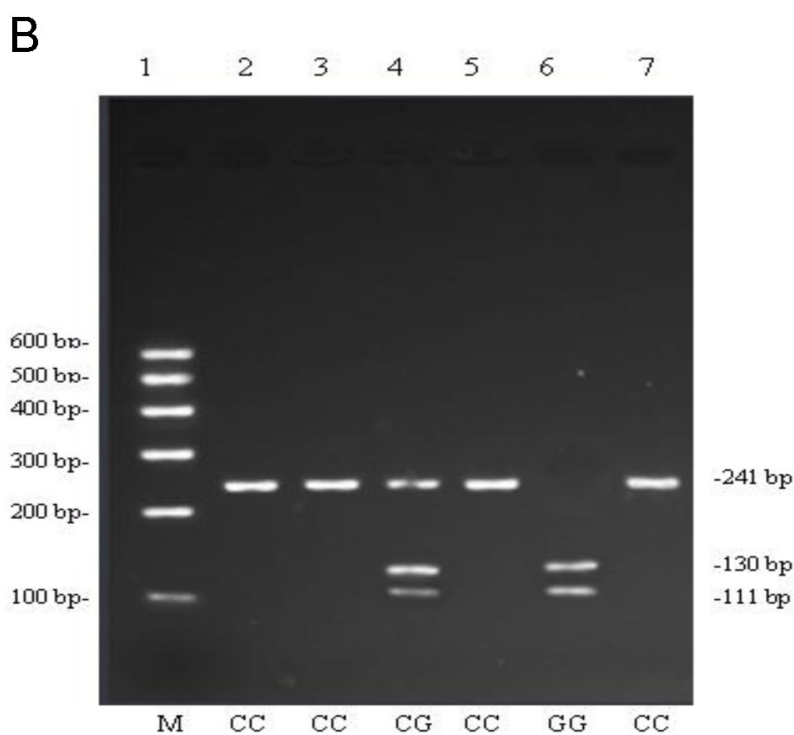

Figure 3. A. Sequencing maps at position NC_007328.3:g.9263C $>\mathrm{G}$ in the goat AGPAT6 gene. B. Electrophoresis patterns of NcoI PCR-RFLP analysis of the goat AGPAT6 gene. $\mathrm{CC}=241 \mathrm{bp} ; \mathrm{CG}=241+130+111 \mathrm{bp} ; \mathrm{GG}=130$ +111 bp. Lane $M=$ marker I $(600,500,400,300,200$, and $100 \mathrm{bp})$.

Moreover, the $16436 \mathrm{G}>\mathrm{A}$ mutation holds a $B g l \mathrm{I}$ endonuclease restriction site (GCCNNNNNGGC), and a 336-bp PCR product digestion with BglI demonstrated two fragments (195 and $141 \mathrm{bp}$ ) for the A allele and only one fragment (336 bp) for the $\mathrm{G}$ allele, and indicated GG, GA and AA genotypes (Figure 4A,B).

The frequencies of genotype and allele were calculated in the two Chinese goat breeds (Table 2). In the PCR-RFLP analysis with KpnI, EcoRII, NcoI, and $B g l$, the frequencies of the $\mathrm{G}$ allele were 0.955 and $0.936,0.694$ and $0.819,0.207$ and $0.254,0.729$ and 0.623 for the two breeds, respectively. $H_{\mathrm{O}}, H_{\mathrm{E}}, N_{\mathrm{E}}$, and PIC were evaluated (Table 3 ). At the $152 \mathrm{G}>\mathrm{C}$ locus, two breeds showed low polymorphism (PIC $<0.250$ ). At the other three loci, the two breeds possessed moderate genetic diversity $(0.250<$ PIC $<0.500)$. 


\section{A}

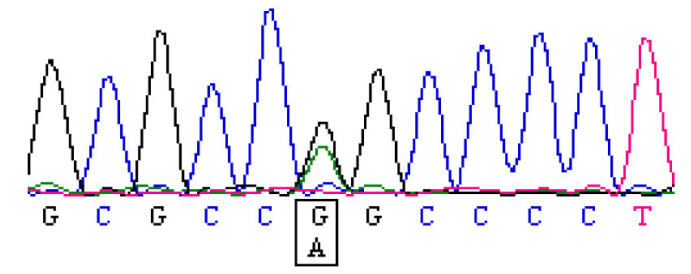

Genotype GA

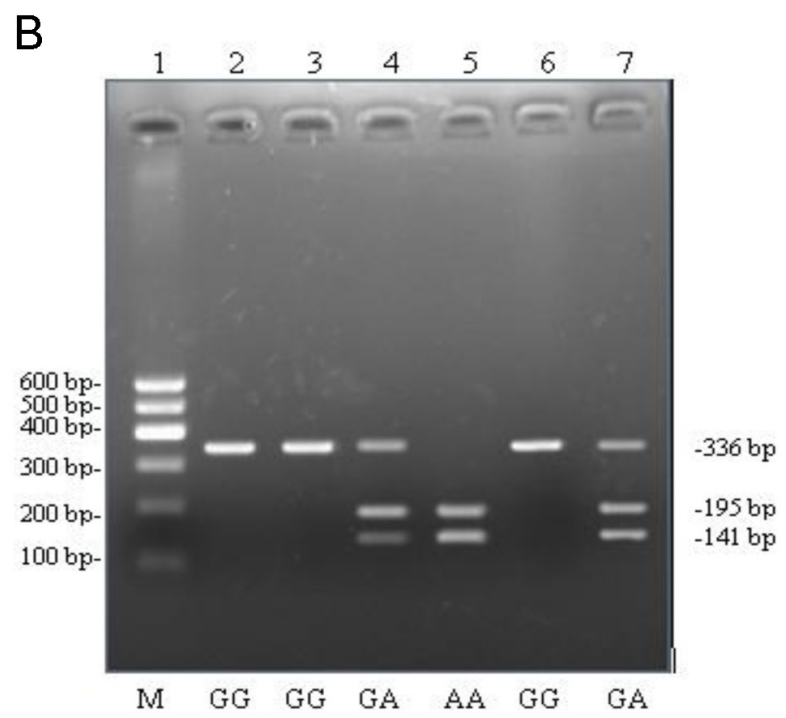

Figure 4. A. Sequencing maps at position NC_007328.3:g.16436G $>$ A in the goat AGPAT6 gene. B. Electrophoresis patterns of $B g l \mathrm{I}$ PCR-RFLP analysis of the goat $A G P A T 6$ gene. $\mathrm{GG}=336 \mathrm{bp} ; \mathrm{GA}=336+195+141 \mathrm{bp} ; \mathrm{AA}=195$ +141 bp. Lane $M=$ marker I $(600,500,400,300,200$, and $100 \mathrm{bp})$.

Table 2. Genotypic and allelic frequencies of AGPAT6 in two goat breeds.

\begin{tabular}{|c|c|c|c|c|c|c|c|}
\hline \multirow{2}{*}{$\frac{\text { Loci }}{K p n \mathrm{I}}$} & \multirow[t]{2}{*}{ Breeds } & \multicolumn{3}{|c|}{ Genotype frequencies } & \multicolumn{3}{|c|}{ Allelic frequencies } \\
\hline & & GG & GC & $\mathrm{CC}$ & Total & $\mathrm{G}$ & $\mathrm{C}$ \\
\hline & $\mathrm{SN}$ & $0.922(247)$ & $0.067(18)$ & $0.011(3)$ & 268 & 0.955 & 0.045 \\
\hline & GZ & $0.890(250)$ & $0.093(26)$ & $0.018(5)$ & 281 & 0.936 & 0.064 \\
\hline \multirow[t]{3}{*}{ EcoRII } & & GG & GA & AA & Total & $\mathrm{G}$ & A \\
\hline & $\mathrm{SN}$ & $0.519(139)$ & $0.351(94)$ & $0.131(35)$ & 268 & 0.694 & 0.306 \\
\hline & GZ & $0.665(187)$ & $0.306(86)$ & $0.029(8)$ & 281 & 0.819 & 0.181 \\
\hline \multirow[t]{3}{*}{ NcoI } & & $\mathrm{CC}$ & $\mathrm{CG}$ & GG & Total & $\mathrm{C}$ & G \\
\hline & SN & $0.694(186)$ & $0.198(53)$ & $0.108(29)$ & 268 & 0.793 & 0.207 \\
\hline & GZ & $0.623(175)$ & $0.246(69)$ & $0.132(37)$ & 281 & 0.746 & 0.254 \\
\hline \multirow[t]{3}{*}{$B g l \mathrm{I}$} & & GG & GA & $\mathrm{AA}$ & Total & $\mathrm{G}$ & A \\
\hline & $\mathrm{SN}$ & $0.593(159)$ & $0.272(73)$ & $0.134(36)$ & 268 & 0.729 & 0.271 \\
\hline & GZ & $0.384(108)$ & $0.477(134)$ & 0.139 (39) & 281 & 0.623 & 0.377 \\
\hline
\end{tabular}

$\mathrm{SN}=$ Xinong Sannen; $\mathrm{GZ}=$ Guanzhong. 
Table 3. $H_{\mathrm{O}}, H_{\mathrm{E}}, N_{\mathrm{E}}$, and PIC at four polymorphic loci of the goat $A G P A T 6$ gene.

\begin{tabular}{llcccc}
\hline Loci & Breeds & $H_{\mathrm{O}}$ & $H_{\mathrm{E}}$ & $N_{\mathrm{E}}$ & PIC \\
\hline KpnI & SN & 0.9145 & 0.0855 & 1.0935 & 0.0819 \\
& $\mathrm{GZ}$ & 0.8801 & 0.1199 & 1.1362 & 0.1127 \\
EcoRII & $\mathrm{SN}$ & 0.5753 & 0.4247 & 1.7382 & 0.3345 \\
& $\mathrm{GZ}$ & 0.7029 & 0.2971 & 1.4227 & 0.2530 \\
$N c o \mathrm{I}$ & $\mathrm{SN}$ & 0.6732 & 0.3268 & 1.4855 & 0.2734 \\
& $\mathrm{GZ}$ & 0.6214 & 0.3947 & 1.6093 & 0.3069 \\
BglI & $\mathrm{SN}$ & 0.6053 & 0.4699 & 1.6520 & 0.3168 \\
& $\mathrm{GZ}$ & 0.5301 & 1.8863 & 0.3595 \\
\hline
\end{tabular}

$H_{\mathrm{O}}=$ gene homozygosity; $H_{\mathrm{E}}=$ gene heterozygosity; $N_{\mathrm{E}}=$ effective allele number; $\mathrm{PIC}=$ polymorphism information content; $\mathrm{SN}=$ Xinong Sannem; GZ = Guanzhong.

In this research, we also revealed an association between the polymorphisms of the AGPAT6 gene and milk traits of two dairy goat breeds. The statistical results showed that, in the NcoI locus, the individuals with genotypes GG and CG have significantly higher milk fat, protein content and milk yield ( $\mathrm{P}<0.05$ or $\mathrm{P}<0.01$, respectively; Table 4$)$ than genotype $\mathrm{CC}$ individuals. No other statistically significant differences were observed between the genotypes of three polymorphic loci (P1-KpnI, EcoRII, BglI) and milk traits in two dairy goat breeds (P $>0.05$; data not shown).

Table 4. Association of the NcoI locus with goat milk traits.

\begin{tabular}{llrrr}
\hline Loci & Milk traits & \multicolumn{3}{c}{ Genotypes } \\
\cline { 3 - 5 } & & \multicolumn{1}{c}{ CC } & CG & GG \\
\hline NcoI & Milk fat (\%) & $3.92 \pm 0.09^{\mathrm{A}}$ & $4.41 \pm 0.15^{\mathrm{B}}$ & $4.55 \pm 0.20^{\mathrm{B}}$ \\
& Protein (\%) & $3.43 \pm 0.05^{\mathrm{a}}$ & $3.64 \pm 0.08^{\mathrm{b}}$ & $3.69 \pm 0.11^{\mathrm{b}}$ \\
& Milk yield (kg) & $587.44 \pm 6.97^{\mathrm{a}}$ & $621.68 \pm 12.97^{\mathrm{b}}$ & $630.17 \pm 17.75^{\mathrm{b}}$ \\
\hline
\end{tabular}

Least squares means in a column with no common superscripts differ significantly; lower-case characters $(a, b)$ represent significance at $\mathrm{P}<0.05$; capital characters $(\mathrm{A}, \mathrm{B})$ represent significance at $\mathrm{P}<0.01$.

\section{DISCUSSION}

In human, overexpression of the AGPAT6 gene showed higher levels of lysophosphatidic acid, phosphatidic acid and GPAT in cells (Chen et al., 2008; Takeuchi and Reue, 2009). Furthermore, substrate specificity studies suggested that AGPAT6 was active against both saturated and unsaturated long-chain fatty acyl-CoAs (Chen et al., 2008). Histological research revealed that milk produced by AGPAT6-deficient mice was markedly depleted in diacylglycerols and triacylglycerols (Beigneux et al., 2006). Besides, a mouse model deficient in AGPAT6 exhibited a $25 \%$ reduction in body weight and resistance to both diet-induced and genetically induced obesity, which further showed its unique role in determining triglyceride content that could not be compensated for by other members of the AGPAT family (Vergnes et al., 2006), while in bovine, it is reported that AGPAT6, together with other genes, coordinately regulate the channeling of fatty acids toward copious milk fat synthesis (Bionaz and Loor, 2008). So, AGPAT6 is crucial for the components and yield of milk. In this study, for NcoI loci, individuals with GG and CG genotypes had higher milk components (milk fat, protein) and 
milk yield than those of the $\mathrm{CC}$ genotype. Although it is a silent mutation, recently there have been some reports about the relationship between the silent mutation and the function of the gene (Kimchi-Sarfaty et al., 2007; Komar, 2007). That is, the protein product with the same acid sequence but different gene sequence had different structural and functional properties. It would be interest to discover how the mechanism for the silent mutation functions. Maybe it changes the character of the protein or it relates with some crucial QTL or gene, which is related to the milk traits.

In conclusion, four novel mutations (NC_007328.3:g.152G $>$ C, 8124G $>$ A, 9263C $>\mathrm{G}$, $16436 \mathrm{G}>\mathrm{A}$ ) were found in the goat AGPAT6 gene. The $9263 \mathrm{C}>\mathrm{G}$ mutation was significantly associated with milk traits. This study may contribute to evaluating it as a genetic marker for dairy goat breeding strategies.

\section{ACKNOWLEDGMENTS}

Research supported by the National " 863" Program of China (\#2008AA10Z138), Research Fund for the Doctor Program of Higher Education of China (\#20080712001), Natural Science Foundation of Jiangsu Province (\#BK2008120) and The Young Topnotch Researcher Support Project of Northwest A \& F University (\#QNGG-2009-007).

\section{REFERENCES}

Agarwal AK, Barnes RI and Garg A (2006). Functional characterization of human 1-acylglycerol-3-phosphate acyltransferase isoform 8: cloning, tissue distribution, gene structure, and enzymatic activity. Arch. Biochem. Biophys. 449: 64-76.

Agarwal AK, Sukumaran S, Bartz R, Barnes RI, et al. (2007). Functional characterization of human 1-acylglycerol3-phosphate-O-acyltransferase isoform 9: cloning, tissue distribution, gene structure, and enzymatic activity. $J$. Endocrinol. 193: 445-457.

Aguado B and Campbell RD (1998). Characterization of a human lysophosphatidic acid acyltransferase that is encoded by a gene located in the class III region of the human major histocompatibility complex. J. Biol. Chem. 273: 4096-4105.

Beigneux AP, Vergnes L, Qiao X, Quatela S, et al. (2006). Agpat6 - a novel lipid biosynthetic gene required for triacylglycerol production in mammary epithelium. J. Lipid Res. 47: 734-744.

Bionaz M and Loor JJ (2008). ACSL1, AGPAT6, FABP3, LPIN1, and SLC27A6 are the most abundant isoforms in bovine mammary tissue and their expression is affected by stage of lactation. J. Nutr. 138: 1019-1024.

Chen YQ, Kuo MS, Li S, Bui HH, et al. (2008). AGPAT6 is a novel microsomal glycerol-3-phosphate acyltransferase. $J$. Biol. Chem. 283: 10048-10057.

Coleman RA and Lee DP (2004). Enzymes of triacylglycerol synthesis and their regulation. Prog. Lipid Res. 43: 134-176.

Kimchi-Sarfaty C, Oh JM, Kim IW, Sauna ZE, et al. (2007). A "silent" polymorphism in the MDR1 gene changes substrate specificity. Science 315: 525-528.

Komar AA (2007). Silent SNPs: impact on gene function and phenotype. Pharmacogenomics. 8: 1075-1080.

Lan XY, Pan CY, Chen H and Zhang CL (2007). An AluI PCR-RFLP detecting a silent allele at the goat POU1F1 locus and its association with production traits. Small Rumin. Res. 73: 8-12.

Nagle CA, Vergnes L, Dejong H, Wang S, et al. (2008). Identification of a novel sn-glycerol-3-phosphate acyltransferase isoform, GPAT4, as the enzyme deficient in Agpat6-/- mice. J. Lipid Res. 49: 823-831.

Nei M and Roychoudhury AK (1974). Sampling variances of heterozygosity and genetic distance. Genetics 76: 379-390.

Sambrook J and Russell DW (2001). Molecular Cloning: A Laboratory Manual. 3rd edn. Cold Spring Harbor Laboratory Press, New York.

Sham P, Bader JS, Craig I, O’Donovan M, et al. (2002). DNA Pooling: a tool for large-scale association studies. Nat. Rev. Genet. 3: 862-871.

Sukumaran S, Barnes RI, Garg A and Agarwal AK (2009). Functional characterization of the human 1-acylglycerol3-phosphate-O-acyltransferase isoform 10/glycerol-3-phosphate acyltransferase isoform 3. J. Mol. Endocrinol. 42: 469-478. 
Takeuchi K and Reue K (2009). Biochemistry, physiology, and genetics of GPAT, AGPAT, and lipin enzymes in triglyceride synthesis. Am. J. Physiol. Endocrinol. Metab. 296: E1195-E1209.

Vergnes L, Beigneux AP, Davis R, Watkins SM, et al. (2006). Agpat6 deficiency causes subdermal lipodystrophy and resistance to obesity. J. Lipid Res. 47: 745-754.

Ye GM, Chen C, Huang S, Han DD, et al. (2005). Cloning and characterization a novel human 1-acyl-sn-glycerol-3phosphate acyltransferase gene AGPAT7. DNA Seq. 16: 386-390. 